\title{
Л.В. ПАНТЕЛЕЙМОНОВА
}

\section{АДМИНИСТРАТИВНО-ТЕРРИТОРИАЛЬНОЕ ДЕЛЕНИЕ В РСФСР (1920-1930-е годы)}

\begin{abstract}
Ключевые слова: административно-территориальное деление, административно-территориальная единица, РСФСР, районирование.
\end{abstract}

\begin{abstract}
В статье рассматривается процесс изменения административно-территориального деления РСФСР в 20-30-е гг. ХХ в. В статье выделяются несколько этапов. Опираясь на историографию и источники, автор пытается проанализировать и обобщить исторический опыт переустройства административно-территориальной системы РСФСР от «стихийного» возникновения новых на фоне существовавших старорежимных административно-территориальных единиц до первой реформы укрупнения, когда окончательно были ликвидированы губернии, волости, уезды, а также второй рефоормы советской власти, сутью которой стало разукрупнение. Исследование показывает, что все преобразования молодой Советской республики в изучаемой сфрере происходили в связи с изменениями фрормы организации власти, а также со сменой принципов региональной политики и курса хозяйственного развития территорий страны. На современном этапе в исследовательской литературе все чаще стали появляться мнения о возврате к губернскому управлению, что и стало предметом подробного анализа автора данной работы. В статье предложены и обоснованы возможные направления совершенствования административно-территориального деления РСФСР после проведенного реформирования в 19201930-е г2. в целях реализации политики больщевиков и дальнейшего территориального развития страны. Выделены основные подходы к формированию административно-территориального деления РСФСР, выявлению локальных социально-экономических систем, определению оптимального размера административно-территориальных образований. Обоснована взаимосвязь административно-территориального деления и экономического районирования в России.
\end{abstract}

Для России с ее огромной территорией система административно-территориального деления (далее АТД) и принципы ее государственного устройства служат одной из основ федерализации страны. Устойчивый интерес к административно-территориальному устройству РСФСР и сопутствующим историческим процессам, к главным действующим лицам формирования новой федеративной модели Советского государства обосновывается прежде всего тем, что данная научная проблема является востребованной в современной отечественной науке. Многие специалисты из разных отраслей знаний активно изучают систему территориально-политической организации «молодой» Республики Советов (1920-1930-е гг.), ведь основа современного территориального устройства Российского государства была заложена именно в те годы. Поэтому накопленный исторический опыт перестройки системы АТД РСФСР будет полезным в фрормировании далеко идущих решений и позволит избежать допущенных ранее ошибок в руководстве и экономике страны.

Именно в 1920-1930-е гг. советская Россия пережила несколько существенных преобразований АТД: от многочисленного увеличения административно- 
территориальных единиц (1924-1929 гг.) до их резкого дробления (1930-е гг.). Все эти нововведения обусловлены особенностями политической и экономической ситуации указанного периода исторического прошлого. С учетом поиска курса более совершенного территориального управления и определения задач социально-экономического роста многонационального государства сложно обосновать административные границы РСФСР. В полной мере рассмотреть эти события и процессы нельзя без их вдумчивого историко-географического осмысления.

Цель статьи - с опорой на историографию и источники проанализировать и обобщить исторический опыт концептуальных положений переустройства АТД РСФСР в 1920-1930-е гг.

При достижении данной цели понадобилось определить следующие основные задачи:

- установить значение понятия «административно-территориальное деление»;

- ознаменовать периоды перестраивания административно-территориального деления РСФСР в рассматриваемый период;

- подтвердить взаимообусловленность административно-территориального деления и экономического районирования России.

Предмет обсуждения заключается в том, что в настоящее время появилось мнение о неэффективности существующей уже многие годы системы АТД страны. Все чаще возникают идеи реформирования и возвращения к губернскому делению территории государства, возникшему в Российской империи еще в XVIII в. Часто муссируется тема очередной реформы укрупнения субъектов РФ [5. С. 326; 8. С. 8; 15. С. 9]. Педалируя необходимость укрупнения административно-территориальных единиц, как правило, называют следующие причины:

1. Дробность системы территориального деления не позволяет увеличить границы хозяйственно-социальной деятельности региональных и местных органов управления;

2. Большое количество территориальных единиц - членов Федерации - порождает несогласованность в их правомочиях и функциях [4. С. 37; 5. С. 34] и т.п.

Осознание необходимости реформирования современной системы АТД породило различные проекты: сразу два проекта АТД России представлены В.В. Кистановым: один, состоящий из двадцати восьми, а другой - из двадцати губерний [8. С. 48]; проект Совета по изучению производительных сил (СОПС), предлагающий девятнадцать регионов [15]. В выделении губерний разработчики проектов нового административно-территориального деления, как правило, опираются на объем валового регионального продукта, численность населения и принцип присоединения слабого региона к более сильному. Имеются проекты, разработанные специалистами-географами, например, АТД России на базе бассейновой концепции (Л.М. Корытный) [9. С. 10]; проект М.К. Шишкова о двадцати новых регионах страны [18. С. 9; 19. С. 10]. Одним из самых «свежих» проектов реформирования АТД на территории РФ предполагает сформировать двадцать крупных регионов вокруг двадцати агломераций [15].

Исторический опыт систематического реформирования АТД говорит о поиске власти эффрективных путей развития государства, который, однако, далеко не всегда приводит к позитивным результатам. Так, например, последнее реформирование АТД России по укрупнению регионов страны, начавшееся 
в 1990-е гг., или реформа по совершенствованию текущей региональной политики для разработки более продуктивных задач, форм и способов администрирования страной, не привела к ожидаемым результатам. Не случайно в Стратегии пространственного развития Российской Федерации на период до 2025 г. (утверждена распоряжением Правительства РФ № 207-р от 13 фревраля 2019 г.), разработанной в рамках целеполагания по территориальному принципу, вновь расписаны те же самые проблемы развития страны. Относительно АТД отметим: высокий уровень социально-экономического неравенства между регионами; малое количество центров экономического роста; высокая доля малопроизводительных и низкотехнологичных производств в структуре экономики субъектов Российской Федерации [16].

Таким образом, разумно обратиться к исторической практике реформирования АТД, которое было комбинированной частью процесса модернизации РСФСР/СССР в период советской власти. Возможно, административно-территориальное деление и экономическое районирование сыграли немаловажную роль в успехах Советского государства, достигшего в предвоенные годы в социально-экономическом развитии достаточно высоких показателей?

На сегодняшний день нет единой точки зрения по формулировке терминов, связанных с системой административно-территориальных единиц. В научной литературе широко применяют такие категории, как «территориально-административное, политико-территориальное, политико-административное, территориально-политическое или политико-государственное деление», «политико-территориальное, национально-государственное или административно-территориальное устройство», или «территориально-политическая организация государства» [3. С. 1; 6. С. 36-328]. Наиболее частым в научных исследованиях является употребление понятия «административно-территориальное деление», или АТД. Вопросы АТД в разнообразных аспектах и с отличной степенью глубины изучаются представителями различных областей научного знания: географами, юристами, регионоведами, политологами, культурологами, социологами и т.д. Многообразие подходов, как утверждает А.А. Редько, привело в отечественной научной литературе к существованию более 140 дефиниций этого понятия [12. C. 3].

Т.В. Соловьева, рассмотрев проблемы терминологии при изучении истории АТД, пришла к выводу, что понятийный аппарат исследований по истории АТД находится в стадии становления, и такой отрасли науки, объектом и предметом которой было бы само АТД, пока не существует. С.А. Тархов, исследуя изменения АТД России на протяжении последних 300 лет, считает: «АТД - это наиболее четко различимая, юридически зафиксированная форма регионализации людей, представляющая собой разделение территории государства на административно управляемые части. А значит, основными процессами реформирования АТД являются увеличение или уменьшение числа административнотерриториальных единиц, что предполагает либо их укрупнение (консолидация мелких в более крупные), либо разукрупнение (дробление, размельчение), а также присоединение к ним участков соседних земель или отсечение (передача) участков территории соседним единицам. Отсюда эти процессы могут обладать устойчивостью и изменчивостью, т.е. быстрой перекройкой сети, укрупнением или измельчением ее ячеек, медленной или быстрой релаксацией стремлением к стабильному равновесию. Как правило, реформирование АТД 
обычно диктуется текущими политическими потребностями государства и изменением принципов территориального управления» [14. С. 24].

Формирование первого социалистического государства, безусловно, коснулось и принципов федерализации советской России, создания в стране особенной системы АТД. Сам процесс образования РСФСР - сложный и противоречивый. Российская Советская Республика, образованная 25 октября (7 ноября) 1917 г., после свержения Временного правительства, не сразу наладила свое государственное устройство, что было очевидно в условиях воссоздании порушенной страны. «Декларация прав трудящегося и эксплуатируемого народа» (1918 г.), выполнявшая потенциальные функции Конституции, преобразовала Российское унитарное государство в федерацию, однако в первое время часто на одной и той же территории одновременно могли действовать несколько Советов рабочих, солдатских и крестьянских депутатов или иные мятежные органы власть предержащие. На периферии, в отдельных губерниях и национальных областях бывшей империи политическую и национальную активность проявляла этническая элита, сыгравшая определенную роль в федерализации России. Конституция РСФСР, принятая 19 июля 1918 г., официально закрепившая название Российской Социалистической Федеративной Советской Республики, утвердила не только структуру власти в РСФСР, но и полномочия ее высших органов управления, а также принципы взаимодействия центра с политическими институтами на местах [11. С. 26].

Начавшаяся Гражданская война подтолкнула большевиков искать новые формы объединения территорий, ранее входивших в состав Российской империи. Уже в 1918-1921 гг. был организован военно-политический союз советских республик (РСФСР, Украины, Латвии, Литвы, Белоруссии, Азербайджана, Армении, Грузии) для «борьбы с мировым империализмом». Это объединение военных, хозяйственных, транспортных и финансовых организаций республик явилось одной из составляющих успеха Республики Советов в Гражданской войне. К 1922 г. появились все необходимые предпосылки для преобразования этого объединения в единый государственный механизм, которым стал Союз Советских Социалистических Республик (СССР). Из всех существовавших вариантов создания нового государства - автономизация (И.В. Сталин), конфедерация (П.Г. Мдивани) и федерация (В.И. Ленин) была избрана федеративная фрорма государственного устройства, при которой строительство государства основывалось на союзе равноправных республик с гарантией суверенных прав каждой из них. При этом признавалось их право на самоопределение.

С образования в 1922 г. и до прекращения существования Союза ССР в 1991 г. границы суверенной союзной РСФСР, как самой крупной по площади, населению и экономической мощи, неоднократно менялись. Наше внимание обращено к первым двум советским реформам районирования, связанным с Гражданской войной, политикой «военного коммунизма» и идеей дальнейшего построения социализма, т.е. с политической стратегией правящей партии большевиков. Этим реформам предшествовал начавшийся после 1917 г. процесс регионализации или перераспределения властных полномочий, передачи функций из центра на региональный уровень, возникновения новых институтов власти на местах. В 1918-1920 гг. полным ходом шла автономизация, т.е. в полосах с нерусским народонаселением (на Урале, в Среднем Поволжье и др.) создавались автономные единицы. В то же время продолжался процесс формирования советских республик на Украине, в Белоруссии, Закавказье, Средней Азии, 
Сибири. В результате на существенной территории Советского государства стартовал процесс размежевания крупных по площади губерний и организации пришедших на смену старых, других административно-территориальных единиц.

В исследовательской литературе происходившие в 1918 - начале 1920 г. преобразования характеризуются как «стихийные», поскольку они носили произвольный, непродуманный, неорганизованный характер [14. С. 24; 20. С. 26]. Границы создававшихся административно-территориальных единиц временами не отвечали экономической конъюнктуре. Поэтому рациональное деление территории диктовало трудоемкое осмысление настоящего вопроса и введение принципов районирования. Первое применение экономического районирования прозвучало в плане ГОЭЛРО, базирующемся на принципах электрифрикации, энергопроизводственном районировании и организации транспортной инфраструктуры. Далее эти вопросы перешли в компетенцию Государственного планового комитета СССР (Госплан), созданного в апреле 1921 г., и Административной комиссии ВЦИК. С первого месяца 1918 г. Совет народных комиссаров (далее Совнарком, СНК) РСФСР обнародует постановление, позволяющее региональным Советам право по своему усмотрению вводить изменения в АТД страны на относившихся в их введении территориях. В результате начинает складываться новая структура АТД: губерния - уезд - волость - сельсовет, а Конституция РСФСР 1918 г. законодательно закрепляет данное положение дел [10. С. 114].

В 1918 г. на общей площади РСФСР образовалось национально-территориальное или автономное новообразование - Трудовая коммуна немцев Поволжья. Через год организована Башкирская АССР. Тогда же из Белорусской ССР в состав РСФСР включены Могилевская, Витебская, Смоленская губернии. Летом 1919 г. из прекратившей свою деятельность Могилевской, а также определенных уездов Черниговской и Минской губерний была основана Гомельская губерния в составе РСФСР. Это был начальный опыт полной перекройки старорежимных губерний. В 1920 г. образованы Татарская АССР, Карельская трудовая коммуна, Марийская и Чувашская автономные области, Киргизская АССР. В 1920-1921 гг. были организованы Дагестанская и Горская АССР, в 1921-1922 гг. возникают Крымская и Якутская АССР и т.д. Как фрорма советской автономии каждая автономная республика имела свою конституцию, гражданство, высшие органы государственной власти и управления, право осуществлять законодательную деятельность, герб, фрлаг, столицу. АССР самостоятельно организовывала свое внутрипостроечное районное деление и ведала иными вопросами административно-территориального устройства, но только в согласии с законодательством союзной республики, в составе которой она состояла.

В 1921 г. убыстрился процесс измельчения больших губерний. Новообразованными губерниями советской поры оказались Череповецкая, Иваново-Вознесенская, Северо-Двинская, Царицынская, Екатеринбургская, Челябинская, Новониколаевская и др. В 1922-1923 гг. из частей старых губерний с доминирующим нерусским населением продолжился процесс образования новых национально-территориальных автономий, создаваемых для удобства управления территориями и решения социально-экономических задач. Область в отличие от АССР не обладала политической самостоятельностью. Так, в 1921 г. была образована Бурят-Монгольская АО, а в 1922 г. - Монголо-Бурятская АО, которые в 1923 г. были объединены в Бурят-Монгольскую АССР. В 1921 г. появляется 
АО Зырян (Коми). Процесс дробления хорошо просматривается на примере Горской АССР, из которой в 1921-1922 гг. выделились Кабардино-Балкарская, Карачаево-Черкесская и Чеченская автономные области [1. С. 13-212].

В 1923 г. на XII съезде ВКП(б) было особо отмечено, что прежнее АТД не соответствует новым политическим и экономическим потребностям СССР. С этого момента на территории РСФСР/СССР начинается реализация плана нового районирования, разработанного Госпланом и Административной комиссией ВЦИК. Еще в 1921 г. обеими организациями были подготовлены проекты районирования РСФСР. Так, Административная комиссия брала за основу принцип типизации регионов, игнорируя экономическое развитие этносов, что повлекло осуждение со стороны Совета национальностей (большая коллегия Наркомнаца). Проект Госплана базировался на тех же подходах, на которые ссылалась комиссия ГОЭЛРО, а именно на транспортном сообщении районов, росте в границах областей только тех фрорм и видов производства, которые не диктовали задействования значительного количества ресурсов, а также на учете энергетического принципа концентрации хозяйств.

В ходе новой реформы начинается упразднение губерний, на основе которых появлялись области, совпадавшие с границами экономических районов, определенных специалистами Госплана. Постановление Президиума ВЦИК от 14 января 1929 г. закрепило решение об абсолютном упразднении губерний, как наследия унитарного государства. В этой связи также ликвидировались административно-территориальные единицы среднего и низшего уровня - уезды и волости. Перед этим внесенные IX Всероссийским Съездом Советов (1921 г.) и ВЦИК IX созыва предложения об уменьшении в целях экономии средств численности административно-территориальных единиц, сильно выросших за время событий революционного 1917 г. Предлагавшееся сокращение коснулось, в первую очередь, волостей и уездов, хотя именно их множество, с позиции позднейшего советского права, и делало РСФСР федерацией. Вместо них создавались округа, районы и сельсоветы как низшие звенья административного деления страны. Названные преобразования проводились на фоне развивавшейся «новой экономической политики» (1921-1928 гг.), т.е. частичного восстановления рыночных механизмов в стране и сворачивания чрезвычайных мер по контролю общества. Реформа реализовывалась на основе консультаций с отечественными учеными, энергетиками, экономистами и географами (Г.М. Кржижановский, И.Г. Александров, Л.Н. Никитин).

Самыми первыми районами, которых коснулось реформирование АТД, стали промышленный Урал и сельскохозяйственный Северный Кавказ. В ноябре 1923 г. ВЦИК вынес решение о создании Уральской области с районно-окружным делением. В состав области вошли площади Екатеринбургской, Тюменской, Пермской и Челябинской губерний. Уральская область, состоявшая из 15 округов, явилась первым субъектом РСФСР/СССР, где Госпланом было осуществлено районирование по естественно-историческим и социально-экономическим показателям. Надо отметить, что в случае, если в составе нового образования имелись национально-автономные объединения, то оно называлось не областью, а краем. Так, в 1925 г. был образован Северо-Кавказский край, вслед за которым создаются Сибирский (1925 г.), Дальневосточный (1926 г.), Нижне-Волжский (1928 г.), Северный (1929 г.), Нижегородский (1929 г., с 1932 г. переименован в Горьковский), Средне-Волжский (1929 г., с 1935 г. переименован в Куйбышевский) краевые объединения [2. С. 559-560]. 
Первый опыт формирования такой административной единицы, как область (на Урале, 1923 г.), повторился в 1927 г. при создании Ленинградской области. Далее возникают: Центрально-Черноземная (1928 г.), Западная (1929 г.), Ивановская Промышленная (1929 г.) и Центрально-Промышленная (1929 г., с 3 июня 1929 г. Московская) области. При этом каждая из новых административно-территориальных единиц объединяли в себе по несколько старорежимных губерний [2. С. 562].

В 1924 г. осуществляется «национально-государственное разграничение» в Средней Азии. В результате размежевания Туркестанской АССР (была в составе РСФСР), Бухарской и Хорезмской ССР были созданы Узбекская и Туркменская ССР, Таджикская АССР и Кара-Калпакская АО в составе РСФСР. Таким образом, южная граница РСФСР в Азии стала проходить по теперешним границам Казахстана и Киргизии.

В процессе проведения первой реформы по укрупнению в 1923-1929 гг. автономная область немцев Поволжья, Карельская трудовая коммуна, а также Чувашская автономная область были преобразованы в АССР немцев Поволжья (1923 г.), Автономную Карельскую ССР (1923 г.) и Чувашскую АССР (1925 г.).

Первая реформа АТД привела к полному исчезновению уездов на территории РСФСР. Они сохранились только в прибалтийских республиках Советского Союза (ликвидированы полностью в 1949-1950 гг.). Такое же административное звено, как округ, упраздняется постановлением ЦИК и СНК СССР от 30 июля 1930 г. Однако в составе РСФСР оставались Ненецкий и Коми-Пермяцкий национальные округа, меньшие по территории, чем губернии. Изначально они образовывались по принципам экономического районирования и входили в состав краев и областей, сами же делились на районы.

Подводя итог вышесказанному, надо отметить, что в результате осуществления политики районирования в 1923-1929 гг., административно-экономической регионализации система регионального и местного уровней управления в РСФСР кардинальным образом была изменена. Советская власть сумела достичь главной цели реформирования страны - упразднения дооктябрьского АТД и формирования крупных, экономически сильных и обладавших большой степенью внутренней независимости областей и краев с округами и районами. Процесс слияния или присоединения административно-территориальных единиц всех звеньев АТД соответствовал, в режиме реального времени, идеям преобразования общества, уравнивания уровней роста районов центральной России и периферии, громадным заданиям народнохозяйственных планов страны. Сформированные крупные административно-территориальные единицы (шесть областей и семь краев) абсолютно совпадали с экономическими районами Госплана. Однако автономные ССР, АО и национальные округа, созданные по национально-территориальному принципу, в большинстве случаев не соответствовали экономическому районированию. Маленькие по площади и немногочисленные по населению национальные автономии входили в состав семнадцати краев и областей, а крупные (в составе РСФСР) образовали Башкирскую, Бурят-Монгольскую, Дагестанскую, Казахскую, Кара-Калпакскую, Карельскую, Киргизскую, Крымскую, Татарскую и Якутскую АССР.

Последняя схема АТД СССР, сорормированная в итоге районирования в 1923-1929 гг., сразу же заработала с перебоями, в первую очередь, это отразилось в округах. С.А. Тархов пишет: «Сами идеи экономического административного района и регионализации хозяйства типа НЭП быстро вошли 
в противоречие с мобилизационной логикой пятилеток, с проведением индустриализации через отраслевые наркоматы. Кроме того, огромные по площади, населению и количеству районов единицы АТД были просто плохо управляемы» [14. С. 30]. Поэтому без промедления в условиях начинавшихся процессов индустриализации и коллективизации была организована и стала реализовываться вторая советская реформа АТД. В научной литературе выделяются две фразы реформирования: первая касалась 1930-1939 гг., а вторая - 1943-1954 гг. Суть этих преобразований заключалась в обратном процессе, а именно в разукрупнении административно-территориальных единиц, или "дерегионализации" управления.

Ранее в апреле 1929 г. на XVI конференции партии была принята резолюция, гласившая о необходимости специального изучения итогов районирования и перелицовки структуры окружного руководства. Е.А. Ширяев отмечает: «Важной составной частью реализации данного партийного решения стало направление в районные центры страны большого числа «проверенных» коммунистов. Летом 1929 г. решением ЦК ВКП(б) и Советского правительства было организовано пять опытно-показательных округов: Армавирский, Челябинский, Курский, два округа УССР и Витебский - БССР. Существо их работы сводилось к тому, что большинство функций окружного исполнительного комитета передавалось райисполкомам, горсоветам и сельсоветам. Окружной исполнительный комитет осуществлял отныне только планирование и контроль работы нижестоящих советских органов управления. Ликвидация отделов окрисполкома освободила окружных партийных работников, и все они были направлены в районные и сельские Советы. И в качестве итога 15 июня по инициативе Сталина И.В. на заседании Политбюро ЦК, а затем 27 июня 1930 г. на XVI съезде ВКП(б) было принято решение о ликвидации округов в масштабе всей страны в целях максимального приближения партийного, хозяйственнокооперативного и профсоюзного аппаратов к району и селу; укрепление областных органов (крайкомов, национальных ЦК) и превращения их в действительных руководителей хозяйственного строительства на местах» [17. С. 38-40]. Напомним, что в эти годы полным ходом шла коллективизация (с 1928 по 1937 г.), проводилась политика объединения мелких и неэффективных единоличных крестьянских хозяйств в коллективные колхозы и совхозы в целях повышения их продуктивности. Сложившиеся крупные хозяйства и их механизация должны были упростить переход рабочей силы и распределение продуктов из аграрного сектора в индустриальный. Неудачи коллективизации (проходила не по плану) Сталин И.В. видел в «оторванности» окружных исполкомов от районов и в слабой укомплектованности «проверенными» кадрами на местах.

Ликвидация округов, завершившаяся к 1 октября 1930 г. на большей части РСФСР, за исключением Казахстана, подразумевала укрупнение районов. Однако советская власть отказывается от массового слияния районов в 1930 г. Советское руководство отныне пытается наладить управление областей и районов в действующих границах. Только деление Сибирского края на ЗападноСибирский и Восточно-Сибирский края стало исключением. В стране была введена 10\%-ная норма сокращения предыдущего числа районов, а в 1934 г. районы снова были разделены на фоне создававшихся машинно-тракторных станций (далее - МТС). Ликвидация округов вновь подтолкнула руководство страны к выстраиванию системы регионального управления. В 1931 г. меняется структура партийных органов, а в 1933-1934 гг. создаются чрезвычайные 
органы партии - в совхозах политотделы МТС, политотделы на железнодорожном и водном транспорте.

Таким образом, постановления Политбюро от 15 июня 1930 г., ЦИК и СНК СССР от 23 июля 1930 г. законодательно закрепили начало новой реформы АТД РСФСР/СССР. Разукрупнение проходило в следующем порядке:

1) деление Дальневосточного края на области: в 1932 г. Амурская, Камчатская, Приморская, Сахалинская; в 1934 г. к ним добавились Нижне-Амурская, Хабаровская, Зейская и Уссурийская. В таком составе край просуществовал до 1938 г.

Практика реформирования АТД Дальнего Востока (Северная область (1933 г.), Читинская область (1934 г.)) путем организации областей в границах краев была реализована и на Северном Кавказе. Но эти области быстро распались. Утверждаемый крайкомом состав создаваемых областных Оргбюро крайкома ВКП(б) и утверждаемые Политбюро первые секретари обкомов не все вопросы могли решать самостоятельно. Поэтому руководством страны образование областей в составе краев было признано неудачным опытом, за исключением Дальнего Востока.

Реформа периода 1930-1933 гг., сводившаяся к организации контроля и управления со стороны региональных партийных и государственных органов над «местными», не затронула сформированные в результате районирования 1920-х гг. «большие» по площади края и области, что отличалось от реформы 1934-1935 гг.;

2) деление нескольких краев и «больших» областей на меньшие по размерам области (1934-1935 гг.).

Изменившаяся система устройства партийных и государственных органов, ее трансформация от функциональной к отраслевой должны были в конечном счете привести к конкретному руководству, к оперативному решению вопросов на местах. Так, предполагалось, что местный руководитель в тесном контакте со своими работниками должен был принимать решения, не ожидая указаний сверху. В 1934 г. были упразднены политотделы МТС. Однако самостоятельность руководящих и партийных органов на региональном уровне была недолгой, уже в 1936-1938 гг. в результате «большого террора» в кадровой политике произошла смена управленческого звена. За эти два года на карте появились 16 новых областей и краев на территории РСФСР: Сибири, Урале, Поволжье, Северном Кавказе, Центре;

3) распад в 1936-1938 гг. всех областей и краев, образованных в 19251929 гг. Самая массовая ликвидация произошла в сентябре 1937 г.

Согласно принятой 5 декабря 1936 г. Конституции СССР, некоторые АССР и все действовавшие на тот момент автономные республики вошли в состав РСФСР. Следовательно, те края, из состава которых выводились АССР, были преобразованы в области: Восточно-Сибирский край, Северный край, Горьковский, Кировский, Куйбышевский, Саратовский, Сталинградский. С 1937 по 1941 г. были созданы семнадцать новых областей и краев.

Таким образом, после всех этих административных реорганизаций в составе РСФСР осталась из «больших» областей только Ленинградская. Новые же области по своим размерами и некоторым очертаниям, а также осуществляемым ими функциям (политическим, административным и хозяйственнонадзорным) напоминали упраздненные в 1923-1929 гг. губернии. 
А.Ю. Саран отмечает: «Сами процессы разукрупнения АТД в 1930-е гг. и укрупнения регионов в 1920-е гг. отличались. Так, при укрупнении регионов создавалась структура и штаты областного центра (партийных, государственных, хозяйственных), определялись внешние границы административно-территориальных единиц, полностью перестраивалась внутренняя структура АТД, организовывалась их связь с новым центром и между собой. А при второй реформе (разукрупнении) структура и штаты региональных организаций новых образований, сформированных из уже существовавшего региона (или из частей нескольких регионов), значительно видоизменялись. Например, изменялся кадровый состав секретарей райкомов и председателей райисполкомов, поскольку многие из них переходили на работу в новый областной центр. Руководили деятельностью по созданию новых областей временные органы Временные бюро ЦК ВКП(б) региона (с 1935 г. они стали называться Оргбюро ЦК ВКП(б)), а также Организационные комитеты ВЦИК. Должности первого и второго секретарей партбюро, председателя исполкома новой административно-территориальной единицы утверждались решением Политбюро сразу же совместно с решением о создании региона. Временные органы власти действовали как полноправные обкомы и исполкомы, осуществляя решение текущих хозяйственных и политических вопросов» [13. С. 41-43].

Постоянные региональные члены аппарата управления избирались на первых региональных конференциях и съездах Советов. При утверждении областных и районных кадров массово практиковалось «выдвижение партии» на руководящую работу. В отдельных регионах руководящих областных работников присылали напрямую по решению центра [7. С. 43]. Следовательно, все эти и подобные им мероприятия в системе управления, поиск более совершенной структуры партийно-государственного аппарата были направлены на решение стоявших перед государством задач, которые менялись в ходе практической реализации курса на социалистическую модернизацию.

Подводя итоги проделанной работы, необходимо отметить, что все преобразования структуры АТД в 1920-1930-е гг. происходили, главным образом, в связи с изменениями политического режима власти, а также со сменой принципов региональной политики и курса хозяйственного развития территорий страны. Исторический опыт реформирования АТД через укрупнение, а затем разукрупнение административно-территориальных единиц следует учитывать при реформировании системы АДТ в современных условиях. В каждом из них есть свои плюсы и минусы, и очень важным является найти золотую середину при практическом решении данного вопроса, тем более следует учитывать, что преобразования в фредерализме России касаются асимметричной федерации, основанной на национально-территориальном принципе.

\section{Литература и источники}

1. Административно-территориальное деление Союза ССР и список важнейших населенных пунктов. С хронологическим перечнем постановлений об изменении границ губерний, областей, республик с 1917 г. до 1929 г. 8-е изд. М.: НКВД, 1929. 25 с.

2. Административно-территориальное деление 16-20 вв. // История отечества с древнейших времен до наших дней. Энциклопедический словарь. М.: БРЭ, 1999. C. $559-565$.

3. Административно-территориальное устройство России: история и современность / под общ. ред. А.В. Пыжикова. М.: ОЛМА-ПРЕСС, 2003. 317 с. 
4. Бугаев В.К. Проблемы районирования для целей совершенствования территориального устройства Российской Федерации // Региональные проблемы России: доклады XII съезда РГО. СПб., 2005. С. 36-43.

5. Государственно-территориальное устройство России (экономические и правовые основы) / А.А. Адамеску, А.Г. Гранберг, В.В. Кистанов, П.Е. Семенов и др.; ред.: А.Г. Гранберг, В.В. Кистанов. М.: ДеКА, 2003. 448 с.

6. Добрынин Н.М. Российский федерализм: становление, современное состояние и перспективы. Новосибирск: Наука, 2005. 429 с.

7. Карелин Е.Г. Создание и функционирование регионального механизма власти в Западной области России (1929-1937 гг.) // Среднерусский вестник общественных наук. 2008. № 1. С. 42-49.

8. Кистанов В.В. Объединение регионов России: преимущества для управления и предпринимательства: к реформе территориального устройства. М.: Экономика, 2007. 139 c.

9. Корытный Л.М. О необходимости и возможности реформирования административно-территориального деления России // Сборник докладов XXV сессии МАРС / под ред. С.С. Артоболевского и Л.М. Синцерова. М.: Институт географии РАН, 2008. С. 5-15.

10. Минеева Е.К. Автономии Среднего Поволжья в системе экономического районирования советской России (20-30-е годы XX века) // Вестник Саратовского государственного социально-экономического университета. 2008. № 1(20). С. 113-117.

11. Минеева Е.К. Наркомнац РСФСР: цели, задачи, структура // Вестник Чувашского университета. 2006. № 7. С. 23-33.

12. Редько А.А. Реформирование административно-территориального деления субъекта РФ как фрактор социально-экономического развития местного самоуправления: дис. ... канд. экон. наук. Курган, 2002.185 с.

13. Саран А.Ю. Исторический опыт административно-территориального деления и реформа 1923-1934 гг. в СССР// Вестник государственного и муниципального управления. 2018. № 1. С. 34-45.

14. Тархов С.А. Изменение административно-территориального деления России за последние 300 лет // География. 2001. № 15. С. 23-30.

15. Усягин А.В., Шишков М.К. Территориальное управление в России: теория, история, современность, проблемы и перспективы [Электронный ресурс] // Территориальное устройство России. URL: http://www.terrus.ru (дата обращения: 20.10.2021).

16. Шамахов В.А., Межевич Н.М. Стратегия пространственного развития Российской Федерации на период до 2025 года: экономические возможности и управленческие ограничения [Электронный ресурс] // Управленческое консультирование. 201. № 4. С. 19-27. DOI: https://doi.org/10.22394/1726-1139-2019-4-19-27 (дата обращения: 21.10.2021).

17. Ширяев Е.A. Реформирование административно-территориального устройства РСФСР в 1930-е годы // Государственное управление. Электронный вестник. 2011. № 26. C. $34-40$.

18. Шишков М.К. О реформе территориального устройства России // География. 2004. № 42(769). C. 8-15.

19. Шишков М.К. Территориальное устройство России: проблемы и перспективы. Самара: [Б. и.], 2009. 364 с.

20. Шульгина О.В. Административно-территориальное деление России в России в XX в.: историко-географический аспект // Вопросы истории. 2005. № 4. С. 25-32.

ПАНТЕЛЕЙМОНОВА ЛЮДМИЛА ВАСИЛЬЕВНА - аспиранТка кафедрЫ отечественной истории, Чувашский государственный университет, Россия, Чебоксары (bibl-achakas@mail.ru). 


\section{Lyudmila V. PANTELEIMONOVA ADMINISTRATIVE-TERRITORIAL DIVISION IN THE RSFSR (1920s-1930s)}

Key words: administrative-territorial division, administrative-territorial unit, the RSFSR, zone division.

The article discusses the process of changes in the administrative-territorial division of the RSFSR in the 20s-30s of the XX century. The article distinguishes several stages. Relying on historiography and sources, the author tries to analyze and summarize the historical experience in reorganization of the RSFSR administrative-territorial system from the "spontaneous" emergence of new administrative-territorial units against the background of the existing old-regime administrative-territorial units to the first consolidation reform, when governorates, volosts, uyezds were finally liquidated, as well as the second reform of the Soviet government, the essence of which was fragmentation. The study shows that all the transformations of the young Soviet republic in the studied area took place in connection with changes in the form of power organization, as well as with a change in the principles of regional policy and the direction of economic development of the country's territories. At the present stage, opinions on the return to the governorate administration began to appear more and more often in the research literature, which became the subject of a detailed analysis by the author of this work. The article suggests and substantiates possible directions for improving the administrative-territorial division of the RSFSR after the reform in the 1920s-1930s in order to implement the policy of the Bolsheviks and further territorial development of the country. The main approaches to the formation of the RSFSR administrative-territorial division, identification of local socio-economic systems, determination of the optimal size of administrativeterritorial entities are highlighted. The interrelation between the administrative-territorial division and economic zone division in Russia is substantiated.

\section{References}

1. Administrativno-territorial'noe delenie Soyuza SSR i spisok vazhneishikh naselennykh punktov. S khronologicheskim perechnem postanovlenii ob izmenenii granits gubernii, oblastei, respublik s $1917 \mathrm{~g}$. do $1929 \mathrm{~g}$. 8-e izd. [The administrative-territorial division of the USSR and the list of the most important settlements. With a chronological list of resolutions on changing the borders of provinces, regions, republics from 1917 to 1929. $8^{\text {th }}$ ed.]. Moscow, 1929, $25 \mathrm{p}$.

2. Administrativno-territorial'noe delenie 16-20 vv. [Administrative-territorial division of the $16^{\text {th }}-20^{\text {th }}$ centuries]. In: Istoriya otechestva $s$ drevneishikh vremen do nashikh dnei. Entsiklopedicheskii slovar' [History of the Fatherland from ancient times to the present day. Encyclopedic dictionary]. Moscow, BRE PUBL., 1999, pp. 559-565.

3. Pyzhikov A.V., ed. Administrativno-territorial'noe ustroistvo Rossii: istoriya $i$ sovremen-nost' [Administrative-territorial structure of Russia: history and modernity]. Moscow, OLMA-PRESS Publ., 2003, 317 p.

4. Bugaev V.K. Problemy raionirovaniya dlya tselei sovershenstvovaniya territorial'nogo ustroistva Rossiiskoi Federatsii [Problems of zoning for the purposes of improving the territorial structure of the Russian Federation]. In: Regional'nye problemy Rossii: doklady $X I I$ s"ezda RGO. [Regional problems of Russia: Reports of the $12^{\text {th }}$ Congress of the RGS]. St. Petersburg., 2005, pp. 36-43.

5. Granberg A.G., Kistanov V.V., eds., Adamesku A.A., Granberg A.G., Kistanov V.V., Semenov P.E. et al. Gosudarstvenno-territorial'noe ustroistvo Rossii (ekonomicheskie i pravovye osnovy) [The state-territorial structure of Russia (economic and legal foundations)]. Moscow, DeKA Publ., 2003, 448 p.

6. Dobrynin N.M. Rossiiskii federalizm: stanovlenie, sovremennoe sostoya-nie $i$ perspektivy [Russian federalism: Formation, current state and prospects]. Novosibirsk, Nauka Publ., 2005, 429 p.

7. Karelin E.G. Sozdanie i funktsionirovanie regional'nogo mekhanizma vlasti v Zapadnoi oblasti Rossii (1929-1937 gg.) [Creation and functioning of the regional mechanism of power 
in the Western region of Russia (1929-1937)]. Srednerusskii vestnik obshchestvennykh nauk, 2008, no. 1, pp. 42-49.

8. Kistanov V.V. Ob"edinenie regionov Rossii: preimushchestva dlya upravleniya $i$ predprinimatel'stva: $k$ reforme territorial'nogo ustroistva [Unification of the regions of Russia: advantages for management and entrepreneurship: towards the reform of the territorial structure]. Moscow, Ekonomika Publ., 2007. 139 p.

9. Korytnyi L.M. O neobkhodimosti i vozmozhnosti reformirovaniya administrativno-territorial'nogo deleniya Rossii [On the necessity and possibility of reforming the administrative-territorial division of Russia]. In: Artobolevskiy S.S., Sintserov L.M. Sbornik dokladov XXV sessii MARS [Collection of reports of the XXV session of MARS]. Moscow, 2008, pp. 5-15.

10. Mineeva E.K. Avtonomii Srednego Povolzh'ya v sisteme ekonomicheskogo raionirovaniya sovetskoi Rossii (20-30-e gody XX veka) [Autonomy of the Middle Volga region in the system of economic zoning of Soviet Russia (20-30s of the $20^{\text {th }}$ century)]. Vestnik Saratovskogo gosudarstvennogo sotsial'no-ekonomicheskogo universiteta, 2008, no. 1(20), pp. 113-117.

11. Mineeva E.K. Narkomnats RSFSR: tseli, zadachi, struktura [People's Com-missariat of the RSFSR: goals, objectives, structure]. Vestnik Chuvashskogo universiteta, 2006, no. 7, pp. 23-33.

12. Red'ko A.A. Reformirovanie administrativno-territorial'nogo deleniya sub"ekta RF kak faktor sotsial'no-ekonomicheskogo razvitiya mestnogo samoupravleniya: dis. ... kand. ekon. nauk [Reforming the administrative-territorial division of the subject of the Russian Federation as a factor of socio-economic development of local self-government. Cand. Diss.] Kurgan, 2002, 185 p.

13. Saran A.Yu. Istoricheskii opyt administrativno-territorial'nogo deleniya $i$ reforma 1923-1934 gg. $v$ SSSR [Historical experience of administrative-territorial division and reform of 1923-1934 in the USSR]. Vestnik gosudarstvennogo i munitsipal'nogo upravleniya, 2018, no. 1 , pp. 34-45.

14. Tarkhov S.A. Izmenenie administrativno-territorial'nogo deleniya Rossii za poslednie 300 let [Changes in the administrative-territorial division of Russia over the past 300 years]. Geografiya, 2001, no. 15, pp. 23-30.

15. Usyagin A.V., Shishkov M.K. Territorial'noe upravlenie v Rossii: teoriya, istoriya, sovremennost', problemy i perspektivy [Territorial administration in Russia: theory, history, modernity, problems and prospects]. Available at: http://www.terrus.ru (Accessed 20 october 2021).

16. Shamakhov V.A., Mezhevich N.M. Strategiya prostranstvennogo razvitiya Rossiiskoi Federatsii na period do 2025 goda: ekonomicheskie vozmozhnosti i upravlencheskie ogranicheniya [The strategy of spatial development of the Russian Federation for the period up to 2025: economic opportunities and managerial constraints] Upravlencheskoe konsul'tirovanie, 2011, no. 4, pp. 19-27. DOI: https://doi.org/10.22394/1726-1139-2019-4-19-27.

17. Shiryaev E.A. Reformirovanie administrativno-territorial'nogo ustroi-stva RSFSR $v$ 1930-e gody [Reforming the administrative-territorial structure of the RSFSR in the 1930s] Gosudarstvennoe upravlenie. Elektronnyi vestnik, 2011, no. 26, pp. 34-40.

18. Shishkov M.K. O reforme territorial'nogo ustroistva Rossii [On the reform of the territorial structure of Russia]. Geografiya, 2004, no. 42(769), pp. 8-15.

19. Shishkov M.K. Territorial'noe ustroistvo Rossii: problemy i perspektivy [Territorial structure of Russia: problems and prospects: monograph], Samara, 2009, $364 \mathrm{p}$.

20. Shul'gina O.V. Administrativno-territorial'noe delenie Rossii v Rossii v XX v.: istorikogeograficheskii aspekt [Administrative-territorial division of Russia in Russia in the XX century: historical and geographical aspect]. Voprosy istorii, 2005, no. 4, pp. 25-32.

LYUDMILA V. PANTELEIMONOVA - Post-Graduate Student of Russian History Department, Chuvash State University, Russia, Cheboksary (bibl-achakas@mail.ru).

Формат цитирования: Пантелеймонова Л.В. Административно-территориальное деление в РСФСР (1920-1930-е годы) // Исторический поиск/ Historical Search. - 2021. - Т. 2, № 4. - C. 55-67. DOI: 10.47026/2712-9454-2021-2-4-55-67. 